\title{
A Scotist Nonetheless? George Berkeley, Cajetan, and the Problem of Divine Attributes*
}

DOI: http://dx.doi.org/10.12775/RF.2018.035

\section{Introduction}

The controversy about the problem of divine attributes ${ }^{1}$ in Ireland started with John Toland's publication of Christianity Not Mysterious (1696) which evoked several responses from various divines such as Peter Browne, ${ }^{2}$

* This research was carried out as a part of my Doc.CH grant by the Swiss National Science Foundation (SNFS): http://p3.snf.ch/Project-172060.

1 Although, it is custom in Berkeley scholarship to refer to this issue as the problem of "divine analogy" (S. H. Daniel, "Berkeley's Rejection of Divine Analogy", Science et esprit 63, no. 2 (2011): 149-151; T. Curtin, "Divine Analogy in EighteenthCentury Irish Philosophy", The Journal of Theological Studies 65, no. 2 (October 2014): 600-604; K. L. Pearce, "Berkeley's Philosophy of Religion", in The Bloomsbury Companion to Berkeley, ed. B. Belfrage \& R. Brook (London \& New York: Bloomsbury, 2017), 470). I speak of the problem of divine attributes. Apart from being a widely used turn of phrase, it is more accurate because everyone agreed analogies are important for divine predication. Yet, they disagreed about the semantical nature of said predications as well as the role analogies play. The discussion was not about whether analogies are the key to solve to semantical aspect of the problem but how these solutions can be spelled out.

2 P. Browne, A letter in answer to a book entitled, Christianity not mysterious as also, to all those who set up for reason and evidence in opposition to revelation $\mathcal{E}$ mysteries. Printed by Joseph Ray in Essex Street, 1697; P. Browne. The procedure, extent, and limits of human understanding. London: Innys \& Manby, 1728. 
Edward Synge, ${ }^{3}$ William King ${ }^{4}$ and of course George Berkeley. Berkeley's most detailed discussion of the issue is found in Alciphron (Alc.) IV, 16-22 (1732). ${ }^{5}$ There Berkeley argues the divine attributes do not differ in kind from their human counterparts and analogical predication is simply the usage of analogies for divine predication (Alc. IV, 21).

In light of this argumentation, Berkeley refers to several "schoolmen" ranging from Pico della Mirandola (Alc. IV, 19) to Aquinas as well as Suárez (Alc. IV, 20) and most notably for my purposes in $\S 21$ to Thomas de Vio's (aka Cardinal Cajetan's) book De Nominum Analogia (DNA) (1498). ${ }^{6}$ While Berkeley (successfully) conveys the impression he is following Cajetan's solution to the problem of divine attributes, the matter is more complicated. Berkeley's own solution bears close resemblance to the position of John Duns Scotus. Ironically, this was precisely the position Cajetan aimed to reject in DNA which is set up as a defense of a Thomist solution to the problem of divine attributes against the criticism of Scotus.

While Berkeley's contemporary Peter Browne already criticized Berkeley's faulty exegesis of Cajetan, Browne's insight seems to have been lost to most contemporary Berkeley scholars. ${ }^{7}$ Although many have pointed out the importance of Cajetan for Berkeley in the context of Alc. IV, 21, ${ }^{8}$ most of them followed James O'Higgins. The latter argued Berkeley follows Cajetan with "remarkable closeness" when dealing with the problem of divine attributes and gives a "fairly accurate

3 E. Synge, A gentleman's religion: in three parts. With an appendix. London: Printed by Richard Sare at Grays-Inn in Holborn, 1697.

4 W. King, Divine Predestination and Foreknowledge, Consistent with the Freedom of Man's will. A Sermon Preach'd at Christ-Church, Dublin, in Archbishop King's Sermon on Predestination, ed. D. Berman \& A. Carpenter (Dublin: Cadenus Press, 1976).

5 Unless explicitly mentioned, references to Berkeley's works are taken from the Luce \& Jessop edition (The Works of George Berkeley Bishop of Cloyne, 9 vols. (London: Nelson, 1948-1957). All the quoted passages from Alciphron remained unaltered by Berkeley in the editions of 1732 and 1752.

6 The references to Cajetan are taken from: Thomas de Vio: De nominum analogia. De conceptu entis, ed. Zammit \& H. Hering (Romae: Institutum Angelicum, 1952).

7 P. Browne, Things Divine and Supernatural Conceived by Analogy with Things Natural and Human, by the Author of the Procedure, Extent and Limits of Human Understanding (London: Innys \& Manby,1733), 477-478. I will not address the question if Browne was right in suggesting Berkeley misrepresented Cajetan (Browne, Divine Analogy, 449-451) or if Berkeley rather misunderstood Cajetan. My focus is primarily on showing - whatever the exact reason - Berkeley failed to do justice to Cajetan's solution of the problem of divine attributes, yet adopted his notion of analogy.

8 W. W. S. March, "Analogy, Aquinas and Bishop Berkeley", Theology 44, no. 264 (June 1942): 321-329; E. W. Van Steenburgh, "Berkeley Revisited", The Journal of Philosophy 60, no. 4 (February 1963): 85. 
account" of Cajetan's scholastic doctrine of analogy. ${ }^{9}$ The notable exception to this rule is Joshua Hochschild who already pointed out "Berkeley has not applied the details of Cajetan's specific theory to the problem". ${ }^{10}$ However, neither does Hochschild point out the remarkable closeness between Berkeley's proposed solution and Scotus' position, nor is it clear if he thinks Berkeley could accept a Cajetinian notion of analogical predication as a mode of literal expression. ${ }^{11}$ Contrary to the latter, I argue Berkeley holds analogical predication simply to be the application of attributes by analogy. Albeit, his notion of analogy is distinctively Cajetinian.

I develop my argument in four steps. First, by outlining Aquinas' treatment of the problem of divine attributes which is prerequisite to understanding Cajetan's central aim in DNA, viz. to defend "analogical predication" as a separate mode of literal expression against Scotus' criticism. Both of which are the topic of the third section. I proceed by showing in what respect Berkeley's own solution does justice to Cajetan's position and more importantly in what respect Berkeley does not represent the latter's position. Rather, Berkeley's solution is very akin to the one Scotus proposed. I close this paper by outlining some systematical advantages of my proposed reading. Although, Berkeley fails, from a contextual point of view, to do justice to Cajetan's solution of the problem of divine attributes it is nonetheless systematically worthwhile to analyze DNA because Berkeley does adopt Cajetan's notion of analogy and metaphor. As I sketch it provides the basis for a more precise understanding of Berkeley's notion of analogy which, in turn, will be useful for the analysis of his notions of likeness in particular and rela-

9 Interestingly, O'Higgins argues for this in light of other criticism in Divine Analogy (J. O'Higgins, "Browne and King, Collins and Berkeley: Agnosticism or Anthropomorphism?", The Journal of Theological Studies 27, no. 1, (April 1976): 96-98). Similar contentions are found in: G. Brykman, "Berkeley et l'analogie des noms", Les Études philosophiques 3, no. 4 (December 1989): 445-453; G. Brykman, Berkeley et le voile des mots (Paris: J. Vrin, 1993), 448-451); T. M. Bettcher, "Berkeley's dualistic ontology", Análisis filosófico 28, no. 2 (November 2008): 162; T. M. Bettcher, Berkeley's Philosophy of Spirit (London \& New York: Continuum, 2007), 57; Daniel, "Berkeley's Rejection", 155-157; Pearce, "Berkeley's Philosophy of Religion", 481 (FN 11) \& K. L. Pearce, "Matter, God, Nonsense", in Berkeley's Three Dialogues: New Essay, ed. S. Storrie (Oxford: OUP, 2018), 190 (FN 26). Although, the latter never explicitly states he agrees with the contention, he does at least not provide any indication $\mathrm{O}^{\prime} \mathrm{Higgins}^{\prime}$ assessment could be incorrect.

10 J. P. Hochschild, "George Berkeley and a theory of analogy", The Downside Review 122, No. 428 (July 2004): 163.

11 Hochschild, "George Berkeley", 157-165. Hence, we cannot call Berkeley either a Thomist or a Scotist in the strict sense. Accordingly, the point I wish to make is not that Berkeley was a Scotist. Rather, if we want to compare Berkeley's solution to proposals of the Scholastics, it is more akin to Scotus' than Cajetan's or Aquinas'. 
tion in general. The latter is especially important if we consider Berkeley treats relations as an "object of human knowledge" on the same footing as ideas and minds (PHK § 89).

\section{The Problem of Divine Attributes}

Although the problem of divine attributes can be traced back to the earliest Christian writers such as Augustine or Boethius, I will restrict my outline of the problem to Aquinas' treatment of it. This restriction suffices to introduce all the necessary distinctions which allow to expose the parallels between Berkeley's and Scotus' position. It is moreover historically justified because Cajetan wished to defend a Thomist solution of the problem of divine attributes against the criticism of Scotus. ${ }^{12}$

While the problem of divine attributes has an ontological aspect, viz. the question if human and divine attributes differ in kind or degree, the focus of this section is on its semantical aspect, i.e. on the question of how we ought to describe these divine attributes with human language. As Aquinas points out in De veritate, there are two ways to speak (modus loquendi) of God; either we speak properly (propriam) or figuratively (figurativam) (De veritate, q. 23 a. 3 co.). I will refer to these two ways of speaking as literal (i.e. proper) and metaphorical (i.e. figurative) modes of speech because what remains implicit when Aquinas names these options is the fact that our language in general only has two different modi: the literal and metaphorical. At first sight, it may seem as if we can only metaphorically (metaphorice) speak of God because everything we predicate of God is taken from the creatures (ST I⿳亠口冋 q. 13 a. 3 arg. 1). Yet, Aquinas insists, "not all names are applied to God in a metaphorical sense, but there are some which are said of Him in their literal sense" (ST I ${ }^{a}$ q. 13 s. c) $)^{13}$ viz. the so-called divine perfections (perfectiones) (ST I ${ }^{a}$ q. 4). This is important because when Aquinas asks, "Whether some names are applied to God and to creatures univocally or equivocally?"14

12 While Cajetan repeatedly professes to follow Aquinas' views (cf. DNA §§ 6, 17, $21,28-30,68,109,123$ etc.) I take this to be an affirmation of his Thomist stance, rather than an attempt to systematize Aquinas. In that regard, I agree with Hochschild's reading of DNA who defends it at length in the first two chapters of his book The Semantics of Analogy: rereading Cajetan's De nominum analogia (Notre Dame: University of Notre Dame Press, 2010). For a different reading see e.g. R. McInerny, Aquinas and analogy (Washington D.C.: CUA Press, 1996), 31-34 or Bettcher, "Dualistic Ontology", 160.

13 Transl. by the English Dominican Fathers. Original: "Non igitur omnia nomina dicuntur de Deo metaphorice, sed aliqua dicuntur proprie".

14 Transl. by the English Dominican Fathers. Original: "utrum nomina aliqua dicantur de Deo et creaturis univoce, vel aequivoce". 
(ST I ${ }^{a}$ pr.) this question is posed within the realm of literal speech. Given it is possible to speak literally of God, Aquinas enumerates the two prima facie options. Call these: "modes of (literal) expression". While univocal predication (univoce praedicari) is made by using a word in the exact same sense, i.e. with the same signification (rationem omnino eadem), something is equivocally (aequivoce) predicated if the word in question is used in a different sense, i.e. with entirely different significations (rationes omnino diversa) (Sententia Metaphysicae, lib. 4 1. 1 n. 7).

Let us now turn to the problem of the divine attributes or "names" (nominum) as Thomas says (ST I ${ }^{a}$ q. 13 pr.). Thomas argues it is impossible to use either univocal or equivocal predication when speaking of God. We cannot use univocal predication because we can only use a word in the same sense if the things they are predicated of are at least generically alike. Yet, (seemingly) there can be no likeness at all (nulla potest esse similitude) between God and created beings or creatures, such as humans, because the latter are only finite (cum creatura sit finite) (De veritate, q. 2 a. 11 arg. 1-2). The problem is not merely one of different degrees. Consider the case of wisdom (sapentia): while "wisdom" predicated of humans only denotes a quality (qualitas) (ST I ${ }^{a}$ q. 13 a. 5 s. c. 1), i.e. something which you can have (more or less of), it does not in the case of God. Rather, God is called "wise" or "good" (bonus) because God is wisdom or goodness (bonitas) itself (SG I c. 33).

This fundamental difference between the nature of God and the creatures renders it impossible to attribute anything of them univocally (SG I c. 32). Hence, it seems divine predications have to be equivocal, i.e. made in a different sense. Aquinas points out this would be problematic because "if that were so, it follows that from creatures nothing could be known or demonstrated about God at all; for the reasoning would always be exposed to the fallacy of equivocation" (ST I q. 13 a. 5 co.). ${ }^{15}$ This, in turn, would lead to an agnostic notion of God. Moreover, it is contrary to the fact that philosophers have proven many things about God (demonstrative de Deo probant) and to what the Bible says (ST Iํ. $\mathrm{q} .13$ a. 5 co..). ${ }^{16}$

15 Transl. by the English Dominican Fathers. Original: “Quia secundum hoc, ex creaturis nihil posset cognosci de Deo, nec demonstrari; sed semper incideret fallacia aequivocationis". The "fallacy of equivocation" was also called a "Four Term Fallacy". Instead of the three terms required for a proper syllogism it contains four because one of the three terms is used in different significations or equivocally.

16 As Thomas points out, not only does the bible say we can understand God by way of understanding created things (Rm. 1: 20) (ST I $\mathrm{I}^{\mathrm{a}} \mathrm{q} .13$ a. 5 co.) but also we are made in his image (imago dei thesis) (Gn. 1: 26) (c ST I⿳⿲丶丶㇒一八⿳亠二口丿 q. 93). The situation gets even worse considering, as Thomas does (cf. SG I 29; De veritate, q. 2 a. 11), the Bible seemingly contains conflicting remarks on the imago dei thesis (cf. Isiah 40: 18; Psalm 70: 19) which raises theological concerns since it contains the word of God. This highlights 
Aquinas seems to face a dilemma: It seems our language is not able to describe God while it is, at the same time, the only means we have to know anything about God. Aquinas does not solve this problem by opting for either mode of literal expression. Rather, he introduces a third mode: "analogical predication" which is supposed to be the medium (medius) between univocal and equivocal predication (ST I ${ }^{\mathrm{a}} \mathrm{q} .13$ a. 5 co.). In distinction to the latter two, the significations of the words in analogical predication are neither entirely the same (omnino eadem) nor absolutely different (omnino diversa) but partly the same (partim non diversa) and partly different (partim diversa) (Sententia Metaphysicae, lib. 4 1. 1 n. 7).

This characterization of "analogical predication" raises many questions. Especially, how can it provide a solution to the problem of divine attributes? However, these questions can be neglected for the present purpose. The important point is that Aquinas understood analogical predication as a mode of literal expression - next to univocal and equivocal predication. Moreover, it is this mode of literal expression which could do justice to the simultaneous likeness and differences between human and divine nature and hence solve the problem of divine attributes (ST Iํ q. 13 a. 6 / SG I c. 34).

\section{A Scotist Attack and a Cajetinian Defense}

The position of Aquinas was famously attacked by John Duns Scotus who argued only univocal predication can evade the fallacy of equivocation (Ord. 1.3.1.1-2, n. 40). ${ }^{17}$ For Scotus meaningful words are either used univocally or equivocally. If a term is used univocally we cannot simultaneously affirm (affirmando) and negate (negando) it of something without a contradiction (Ord. 1.3.1.1-2, n. 26). For example, it is not possible without contradiction to univocally predicate Socrates is and is not human while we can, without contradiction, (equivocally) predicate

Aquinas' concerns were not merely semantical or epistemological. Rather, theological concerns are a major factor for introducing analogical predication. Moreover, Aquinas does provide an ontological solution to the problem of our simultaneous (un-) likeness with God: we are like God as we try to imitate God but unlike God as we can

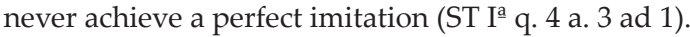

17 Although the target of Scotus' argumentation was more likely Henry of Ghent than Aquinas (Ord. 1.3.1.1-2, n. 20) I assume - following Richard Cross - the arguments apply mutatis mutandis to Aquinas (Duns Scotus. Great Medieval Thinkers (New York: Oxford University Press, 1999), 34-37). This is moreover historically justified in the context of my argument because Cajetan refers to the version of this argument from the Ordinatio (formerly Opus oxoniense) when defending his Thomist position (DNA § 113). 
Socrates hits the ball with a bat (piece of wood) but not with a bat (nocturnal mammal).

Contrary to Aquinas, Scotus does not think we can evade the fallacy of equivocation by using analogical predication. He does not even believe there is a separate third mode of literal expression. Rather, analogical predication is reducible to equivocal (Lec. 1.3.1.1-2, n. 11). At least both modes lead to syllogisms with four terms, i.e. a fallacy of equivocation. This worry becomes evident when Scotus argues we cannot even understand the signification (ratio) of wise (sapiens) when applied to God unless it is attributed univocally, i.e. if it has the same signification as when attributed to the creatures. Otherwise, we could just as well say "God is a stone (lapis)" since "stone" would signify something else anyway (Ord. 1.3.1.1-2, n. 39-40). If we do not use univocal predication, it would be possible to say anything about God which in turn would lead to the perishing (periret) of theology (Lec. 1.3.1.1-2, n. 113) because we could know nothing about God.

Scotus thought univocal predication was the only option to ensure a syllogism consists of three terms only, i.e. to evade the fallacy of equivocation. Given this criticism, the challenge for later Thomists, such as Cajetan, was to show how analogical predication was distinct from the other modes of literal expression while showing how it does not fall prey to the fallacy of equivocation.

Although Cajetan took Scotus' criticism seriously - which is obvious as he devotes the whole Chapter Ten of DNA to dealing with it - he was not convinced it was a decisive objection. On the contrary, he not only followed Aquinas in understanding analogical predication as a separate mode of literal expression: viz. as the medium between univocal and equivocal predication (DNA $\S \S 31$ \& 61) but also in holding it to be the key to solve the problem of divine attributes (DNA $\S \S 82,109-110)$. Yet, because of Scotus it was necessary to clarify more precisely how this solution works. In this context, Cajetan introduces three modes of analogy (DNA § 3):

i) The analogy of inequality (analogiam inequalitas)

ii) The analogy of attribution (analogiam attributionis)

iii) The analogy of proportion (analogia proportionalitas)

These modes do not simply describe three different ways of analogical predication in the sense of a separate mode of literal expression. Rather, analogical predication has a double meaning in Cajetan's writings. Apart from the previously introduced mode of literal expression, it can also denote a predication made by an analogy. ${ }^{18}$

18 The idea that analogical predication also concerns the (semantical) form of the predication is already implicit in Aquinas (cf. De veritate, q. 2 a. 11). 
Analogies are comparisons based on similarity. Cajetan's threefold distinction is one of three kinds of comparisons distinguished according to their structure and the similarity of their relata. The latter, in turn, is the key to explain why only the analogy of proportion allows for genuine analogical predication - i.e. not only in the sense of a predication made by analogy but of a separate mode of literal expression. This is why Cajetan says it is "the only analogy properly deserving the name" (sola proprie analogia vocetur) (DNA § 23) while he rejects the analogy of inequality (DNA § 7) and the analogy of attribution (DNA §§ 19-21) for only allowing univocal and equivocal predication respectively.

The analogy of proportion, which Cajetan introduces in the third chapter and elaborates in the rest of the book, is a comparison of two similar relations. Originally used in mathematics to describe the similarity of two proportions (similitude duarum proportionum) such as 8 to 4 and 6 to 3. Subsequently, the term "proportion" has been extended (extenderunt) to describe any similarity of relations (habitudinum) (DNA § 24) according to the well-known scheme A:B::C:D.

In light of this four-term structure Cajetan's choice is surprising because how could this structure help to evade the fallacy of equivocation? According to Cajetan the similarity of relations or "proportionality" is able to do so since it leads to a proportional unity between the significations (ratios) (DNA $\S 23$ ). ${ }^{19}$ Cajetan argues this proportional unity of significations is one without mixture (coniunctim) or separation (disiunctim) of the significations in questions (DNA § 111). According to Cajetan, this was overlooked by Scotus and his followers when they rejected analogical predication. Their analysis was one-sided in that they only focused (inspicientes) on the differences but failed to pay attention to (non considerat) what is common (DNA § 106). Hence, they did not realize wisdom (sapentia) can be analogically predicated of God and the creatures because although wisdom does not signify the same in each instance their significations (rationem) are proportionally one (unam) (DNA § 111) and hence a syllogism would only consist of three terms (DNA § 109). ${ }^{20}$

The previous characterization of Cajetan's views suffices for my argument. The important points for which are:

i) The idea that predications may be called analogical because they are made by an analogy.

19 Although this sounds circular and Cajetan has indeed been accused of circularity, I will not deal with this issue here since it does not impede on my argument. Yet, I agree with Hochschild the circularity-objection can be rejected (Hochschild, Semantics of Analogy, 132-139).

20 As Hochschild pointed out Cajetan adopts this notion of proportional unity from Aristotle (Metaphysics 5.6 1016b31-1017a2) in order to highlight the "metaphysical mistake" made by Scotists, i.e. "the failure to grasp the reality, even the possibility, of proportional unity" (Hochschild, "George Berkeley", 161). 
ii) The rejection of Scotus' criticism by defending the Thomist conception of analogical predication as a separate mode of literal expression which is done by:

iii) introducing a specific mode of analogy - viz. the analogy of proportions (A:B::C:D).

If a predication is made according to this mode of analogy, it enables analogical predication as a separate mode of literal expression by providing a proportional unity of significations which prevents the fallacy of equivocation.

\section{The Parallels between Berkeley's and Scotus' Solutions}

With this background in mind, let us turn to Berkeley's Cajetan exegesis in Alc. IV, 21. Berkeley, or rather one of his spokesmen, Crito, starts the section by saying:

But, to prevent any man's being led, by mistaking the Scholastic use of the terms analogy and analogical, into an opinion that we cannot frame in any degree a true and proper notion of attributes applied by analogy, or, in the School phrase, predicated analogically, it may not be amiss to inquire into the true sense and meaning of those words. ${ }^{21}$

Although, he is not explicitly referring to Cajetan at this point, the latter's influence is already recognizable. As I pointed out in the previous section, the notion of analogical predication not only as a mode of literal expression but as a predication done by analogy is very important for Cajetan's argument. Moreover, the following inquiry into the "true sense and meaning" of analogy and analogical is nothing less than a translated paraphrase of the third chapter of DNA. Berkeley starts by highlighting the Greek origin (DNA § 28) and the originally mathematical usage of analogies (DNA § 24). Additionally, he provides two examples to be found in DNA $\S \S 23 \& 28$. He even includes a footnote referring to the third chapter: "Vide Cajetan, de Nom. Analog., c. 3" (Works III, 169). ${ }^{22}$

In light of all this, it is safe to assume Berkeley adopts the previously mentioned understanding of analogical predication as a predication done by analogy from Cajetan as well. The important question arising

${ }^{21}$ Alc. IV, 21, 169.

22 Jessop and Luce fail to mention both examples can be found in Aquinas, rather than only the prince and the pilot (Works III, 169). For the intellect/sight example, cf. De veritate, q. 2 a. 11 co. 
from thence: does he also adopt Cajetan's notion of analogical predication as a separate mode of literal expression?

At first sight, it seems as if Berkeley does. Especially, if we consider that most of Berkeley's contemporaries, contrary to most Scholastics, treated analogical predication not as a separate mode of literal expression but of speech. Take the example of William King who argues in his sermon on Divine Predestination (1709) we should "ascribe these attributes [referring to the perfectiones] to God...by analogy" (§ 4). However, King tries to distinguish these analogical predications from literal ( $\$ \S 6$, $14,22,35 \& 36)$ as well as metaphorical speech (\$§ 21-22). Thusly, King treats these predications in an "analogical sense" (§ 33) on equal footing with predications made in the literal or metaphorical sense. Hence, when Berkeley insists in Alc. IV, 21 analogical predication should be considered as part of literal speech he is in that regard very faithful to Cajetan's understanding of analogical predication..$^{23}$

However, Berkeley's insistence that analogical predication should be considered as a part of literal speech does not straightforwardly imply he accepted analogical predication as a separate mode of literal expression. While the former was also accepted by Scotus and many of his followers, the latter understanding was unique to Thomists such as Cajetan. However, Berkeley's following elaborations give no indication he adopted this Thomist understanding. On the contrary, looking at the solution Berkeley advances in the following, it becomes evident his position is closer to Scotus than Cajetan. In that regard, it is more than telling Berkeley never uses "proportional unity" or "identity" when explaining "what Cajetan calls analogia proprie facta" (Alc. IV, 21, 170). ${ }^{24}$ Not to mention, Cajetan never uses the phrase analogia proprie facta in DNA at all. While this may simply be a slip of the pen, Berkeley's explanation of how it solves the problem of divine attributes hardly is:

23 Berkeley uses proper as the translation for propriam instead of literal (cf. e.g. King in §5). Yet, not only does proper traditionally refer to literal speech, Berkeley explicitly assimilates the two - at least in context of the problem of divine attributes when criticizing King's sermon, i.a. for the insufficient distinction between metaphor and analogy, shortly after its publication (Letter 12 in M. A. Hight, The correspondence of George Berkeley (Cambridge: CUP, 2015), 36).

24 "Proportionality", i.e. proportionalitas, is only used once by Berkeley in $\S 25$ of the Analyst, although in a mathematical context. Pascal Taranto only recently provided an interesting discussion about the difference of proportion and proportionality and its implications for the problem of divine attributes (cf. his presentation: "Berkeley, Browne, and Divine Analogy" (June 2018)). While Taranto also provided insights to the mathematical, or rather Euclidian, roots of this notion of analogy, he does not pay attention to Berkeley's faulty Cajetan exegesis and almost Scotist solution. 
And after this same analogy [referring to analogia proprie facta; MF] we must understand all those attributes to belong to the Deity which in themselves simply, and as such, denote perfection [i.e. the perfections; MF]. We may, therefore, consistently with what hath been premised, affirm that all sorts of perfection which we can conceive in a finite spirit are in God, but without any of that alloy which is found in the creatures. ${ }^{25}$

Apart from the traditional thesis only perfections such as wisdom and goodness can be literally attributed to God, Berkeley suggests the blueprint of such attributes is found in finite spirits (i.e. created beings or creatures). Berkeley argues we only have to remove the imperfections of these attributes, which they exhibit due our finiteness, to get a "direct or proper notion, though never so inadequate, of knowledge or wisdom, as they are in the Deity" (Alc. IV 21, 170). ${ }^{26}$

Berkeley's explanation seems to be at odds with Cajetan's solution which does not require any removing (of imperfections) whatsoever. Rather, Cajetan tried to explain how human and divine wisdom can be one, despite being different (DNA § 111). The difference between their solutions emerges most clearly in Alc. IV, 22 where Berkeley uses the fallacy of equivocation to make his point:

...the same arguments that prove a first cause proving an intelligent cause; intelligent, I say, in the proper sense; wise and good in the true and formal acceptation of the words. Otherwise, it is evident that every syllogism brought to prove those attributes, or (which is the same thing) to prove the being of a God, will be found to consist of four terms, and consequently can conclude nothing. But for your part, Alciphron, you have been fully convinced that God is a thinking intelligent being, in the same sense with other spirits, though not in the same imperfect manner or degree. ${ }^{27}$

Cajetan solved the problem of the fallacy of equivocation by providing an account of how analogical predication leads to the unification of two of the four terms and hence a valid syllogism. However, none of this is found in Berkeley's argument. On the contrary, Berkeley uses the fallacy of equivocation to show predications of humans and God are made in the same sense. Rather than explaining how analogical predication as a mode of literal expression could evade the fallacy, Berkeley echoes a very Scotist point: viz. only univocal predication can evade the fallacy of equivocation. Similarly to Scotus, Berkeley does not try to do

25 Alc. IV 21, 170.

26 Berkeley made the same proposal as early as 1713 in the Three Dialogues (DHP 231-232).

27 Alc. IV 22, 171, my emphases. 
justice to God's different nature by using a special mode of literal expression. Rather, Berkeley insists there is a gradual difference between the natures of God and humans which is why we have to use analogies in the first place. Yet, we can predicate certain attributes univocally of God and humans. ${ }^{28}$

In conclusion, Berkeley does justice to Cajetan's solution inasmuch as he is right to point out, against a prevalent conception of his contemporaries that analogical predication should be considered as a part of literal speech. However, Berkeley clearly departs from Cajetan when he argues these predications are made in the same sense. In that regard, his position is very akin to Scotus'. From today's point of view, Berkeley's univocal solution is closer to Scotus' than Cajetan and hence, ironically, closer to a position Cajetan aimed to reject in the first place.

\section{Berkeley's Cajetinian Notion of Analogy and Metaphor}

Despite the faulty Cajetan exegesis by Berkeley, which has to be criticized from a contextual point of view, considering DNA proves to be systematically useful. It provides insights into Berkeley's philosophy because Berkeley not only paraphrases Cajetan but also adopts his notions of analogy and of (some) metaphors as analogies. As the quote from the beginning of the previous section already clarified, Berkeley uses the paraphrase of Cajetan's third chapter in DNA to explain the "true sense and meaning" of analogy:

Every one knows that analogy is a Greek word used by mathematicians to signify a similitude of proportions. For instance, when we observe that two is to six as three is to nine, this similitude or equality of proportion is termed analogy. And, although proportion strictly signifies the habitude or relation of one quantity to another, yet, in a looser and translated sense, it hath been applied to signify every other habitude; and consequently, the term analogy comes to signify all similitude of relations or habitudes whatsoever. ${ }^{29} \ldots$ For the farther clearing of this point, it is to

28 A similar point is made by Cross in regard to Scotus' solution: "[ $t$ ] he difference between God and creatures, at least with regard to God's possession of the pure perfections, is ultimately one of degree. Specifically, the perfections exist in an infinite degree in God, and in a finite degree in creatures " (Cross, Duns Scotus, 39).

29 Compare: Quamvis autem proportio vocetur certa habitudo unius quantitatis ad aliam, secundum quod dicimus quatuor duplam proportionem habere ad duo; et proportionalitas dicatur similitudo duarum proportionum, secundum quod dicimus ita se habere octo ad quatuor quemadmodum sex ad tria utrobique enim dupla proportio est, etc.; transtulerunt tamen Philosophi proportionis nomen ad omnem 
be observed that a twofold analogy is distinguished by the Schoolmen, metaphorical and proper. ${ }^{30}$

Following Cajetan, Berkeley not only points out the mathematical origin, but understands analogies as comparisons involving a similarity of relations according to the scheme A:B::C:D which can be called proper or metaphorical. However, Berkeley does not explicate how these relations are similar. Following Hochschild I propose to speak of a "functional similarity" by which I mean a likeness of purpose: two relations are functionally similar if A serves the same purpose (for B) as C does for D. ${ }^{31}$

We might consider the example Berkeley adopts from Cajetan, of the analogy between intellect and sight which are the same "forasmuch as the intellect [A] is to the mind [B] what sight [C] is to the body [D]" (Alc. IV, 21, 169). While Berkeley does not explicate inasmuch they are the same, an explanation can be found in DNA. In § 23, Cajetan explains the analogy between intellect and sight holds because both allow, mind and body respectively, to see (videre). Of course, this does not entail we see precisely the same way by intellect and sight. On the contrary, Cajetan makes clear this is not the case by writing of videre corporali vision and videre intellectualiter. However, it is precisely because intellect and sight serve the same purpose we can even speak of videre in both cases. More importantly, videre is not used in a metaphorical sense but literally because neither the nature of intellect nor of sight prevents the predication of videre in a literal sense. This in distinction to the case where a blooming field (prato virenti) is called smiling (ridens) (DNA § 25). While the blooming of flowers is functionally similar to a smiling mouth (i.e. it pleases people), fields of flowers are not the kind of entities which can be properly or literally speaking said to smile. For this they would need a mouth as well as an intellect. ${ }^{32}$

habitudinem conformitatis, commensurationis, capacitatis, etc. Et consequenter proportionalitatem extenderunt ad omnem similitudinem habitudinum. Et sic in proposito vocabulis istis utimur (DNA § 24).

30 Alc. IV, 21, 169f. Compare: Fit autem duobus modis analogia haec: scilicet metaphorice et proprie (DNA § 25).

31 Hochschild, The Semantics of Analogy, 2. For the present consideration we may neglect the question how "objective" or "God given" these purposes are. Although, it is likely Berkeley understood them to be at least as partly objective. For Berkeley does not only accept "final causes" but thinks philosophers should consider the "various ends, to which natural things are adapted, and for which they were originally with unspeakable wisdom contrived" (PHK § 107).

32 While this explanation is absent in DNA it can be found in Aquinas (cf. ST III q. 23 a. 3 arg. 3 \& q. 24 a. 2 ad 2) from whom Cajetan probably adopted this example. Moreover, it was a Scholastic standard example for a metaphor. Berkeley does not use this example at all but the (metaphorical) predication of body parts and passions 
Although this line of reasoning relies heavily on an ontology based on the Aristotelian categories which is not easily reconcilable with Berkeley's immaterialism, the important point for my purpose is the following: the idea that videre is used literally when predicated of intellect or sight is in principle perfectly acceptable for Berkeley. In fact, Cajetan's use of videre is akin to Berkeley's broad (but literal) use of "perceive" when e.g. saying of ideas of imagination as well as sense "their esse is percipi" (PHK § 3). While the ideas of sense are "real things" the ideas of imagination are only their "copies" and hence there are obvious differences in perceiving either (PHK $\S \S 8$ \& 34) - e.g. under normal circumstances we need our sense organs to perceive the former.

Moreover, adopting Cajetan's notion of metaphors as analogies does not imply Berkeley has to accept the Aristotelian categories, despite Cajetan's explicit acceptance of the latter (DNA $\S \S 5,11,19,28 \& 58$ ). It suffices Berkeley does accept while some metaphors are analogies, there are some analogies that do not include metaphorical speech but only words used in their "proper signification" (Alc. IV, 21, 170). Of course, it will be necessary to spell out what this proper meaning entails and how it is distinguished from improper signification. Yet, if my reading is correct, this, taken together with Berkeley's notion of functional similarity as well as its relation to Berkeley's notion of likeness in general, are some of the main tasks ahead.

\section{Conclusion}

The aim of this paper has been to show Berkeley's solution to the problem of divine attributes is closer to Scotus than Cajetan. For this it was prerequisite to introduce said problem as Aquinas conceived of it. Most importantly, Aquinas introduced analogical predication as a separate mode of literal expression which he argued would solve this problem. While Scotus attacked this Thomist solution by arguing it would lead to the fallacy of equivocation, Cajetan set out to defend it against this criticism in De Nominum analogia.

Although Berkeley refers to Cajetan's book and moreover adopts his notion of analogy as a comparison of functionally similar relations, Berkeley does not embrace Cajetan's Thomist understanding of analogical predication as a separate mode of literal expression. Rather, Berkeley defends a position akin to Scotus' according to which the difference between God and humans is merely gradual which allows for univocal

of God. Although, he follows the same rationale when he says that e.g. in case of a finger "it is as truly ascribed to God as the works wrought by human fingers are to man" (Alc. IV, 21, 170). 
predication. For Berkeley, analogical predication is just one done by using an analogy while the predicated words are used in the same sense when applied to the divine and human. ${ }^{33}$

\section{Bibliography}

Aristoteles. Metaphysics. Edited by William David Ross. Oxford: Clarendon Press, 1924.

Aquinas, Thomas, Summa Theologiae. Translated by the English Dominican Fathers. London: Burns, Oates, and Washburne, 1912-36; New York: Benziger, 1947-1948; New York: Christian Classics, 1981.

Aquinas, Thomas, Commentary on the Metaphysics of Aristotle. Translated by J. P. Rowan. Chicago: Henry Regnery Co., 1962.

Aquinas, Thomas. The Disputed Questions on Truth. Vol. 1 translated by Robert William Mulligan, S.J. Chicago: Henry Regnery Co., 1952.

Aquinas, Thomas. Summa Contra Gentiles. Translated by the English Dominican Fathers. London: Burns, Oates, and Washbourne, 1934.

Berkeley, George. The Works of George Berkeley Bishop of Cloyne. 8 vol., edited by A. A. Luce \& T. E. Jessop. London: Nelson, 1948-1957.

Bettcher, Talia Mae. "Berkeley>s dualistic ontology". Análisis filosófico 28, no. 2 (November 2008): 147-173.

Bettcher, Talia Mae. Berkeley's Philosophy of Spirit. London \& New York: Continuum, 2007.

Browne, Peter. A letter in answer to a book entitled, Christianity not mysterious as also, to all those who set up for reason and evidence in opposition to revelation $\mathcal{E}$ mysteries. Printed by Joseph Ray in Essex Street, 1697.

Browne, Peter. The procedure, extent, and limits of human understanding. London: Innys \& Manby, 1728.

Browne, Peter. Things Divine and Supernatural Conceived by Analogy with Things Natural and Human, by the Author of the Procedure, Extent and Limits of Human Understanding. London: Innys \& Manby,1733.

Brykman, Geneviève. "Berkeley et l'analogie des noms". Les Études philosophiques 3, no. 4 (December 1989): 445-453.

Brykman, Geneviève. Berkeley et le voile des mots. Paris: J. Vrin, 1993.

Caietanus, Thomas de Vio: De nominum analogia. De conceptu entis, edited by N. Zammit \& H. Hering. Romae: Institutum Angelicum, 1952.

Cross, Richard, Duns Scotus. New York: Oxford University Press, 1999.

33 I want to thank all the participants - especially John Blechl, Adam Grzeliński, Kenneth Pearce, Tom Stoneham, and Peter West - of the 2017 IBS conference "Berkeley's Philosophy after the Principles and the Three Dialogues" in Torun for their comments and criticisms of this paper. Moreover, I want to express my gratitude to Margaret Atherton, Pascal Taranto, and Yann Wermuth as well as the editor, and the anonymous reviewer for their suggestions and feedback on earlier version of this paper. 
Curtin, Thomas. "Divine Analogy in Eighteenth-Century Irish Philosophy". The Journal of Theological Studies 1. 65, no. 2 (October 2014): 600-624.

Daniel, Stephen H. "Berkeley's Rejection of Divine Analogy". Science et esprit 63, no. 2, 2011: 149-161.

Hight, Marc A. The correspondence of George Berkeley. Cambridge: CUP, 2015.

Hochschild, Joshua P. The Semantics of Analogy: rereading Cajetan's De nominum analogia. Notre Dame: University of Notre Dame Press, 2010.

Hochschild, Joshua P. "George Berkeley and a theory of analogy", The Downside Review 122, no. 428 (July 2004): 157-168.

King, William. Divine Predestination and Foreknowledge, Consistent with the Freedom of Man's will. A Sermon Preach'd at Christ-Church, Dublin. In Archbishop King's Sermon on Predestination, edited by David Berman \& Andrew Carpenter (SEITEN). Dublin: Cadenus Press, 1976.

March, W. W. S. "Analogy, Aquinas and Bishop Berkeley". Theology 44, no. 264 (June 1942): 321-329.

McInerny, Ralph. Aquinas and Analogy. Washington, D.C: Catholic University of America Press, 1996.

O'Higgins, James. "Browne and King, Collins and Berkeley: Agnosticism or Antrhopomorphiosm?". The Journal of Theological Studies 27, no. 1 (April 1976): 88-112.

Pearce, Kenneth L. "Berkeley's Philosophy of Religion", In: The Bloomsbury Companion to Berkeley, edited. Bertil Belfrage \& Richard Brook, 458-483. London \& New York: Bloomsbury, 2017.

Pearce, Kenneth L. "Matter, God, Nonsense". In Berkeley's Three Dialogues: New Essay, edited by Stefan Storrie, 176-190. Oxford: OUP, 2018.

Sancti Thomae de Aquino, Opera omnia iussu Leonis XIII P. M. edita, t. 22: Quaestiones disputatae de veritate (Ad Sanctae Sabinae/Editori di San Tommaso, Roma, 1975-1970-1972-1973-1976) 3 vol. 5 fascicula.

S. Thomae Aquinatis, In duodecim libros Metaphysicorum Aristotelis expositio. Ed. M. R. Cathala, R. M. Spiazzi (2 ${ }^{\underline{a}}$ ed.: Marietti, Taurini-Romae, 1971).

S. Thomae Aquinatis, Liber de veritate catholicae Fidei contra errores infidelium seu Summa contra Gentiles, t. 2-3. Ed. P. Marc, C. Pera, P. Caramello (Marietti, Taurini-Romae, 1961).

S. Thomae Aquinatis, Opera omnia iussu impensaque Leonis XIII P. M. edita, t. 4-5: Pars prima Summae theologiae, (Ex Typographia Polyglotta S. C. de Propaganda Fide, Romae, 1888-1889).

S. Thomae Aquinatis, Opera omnia iussu impensaque Leonis XIII P. M. edita, t. 11-12: Tertia pars Summae theologiae, (Ex Typographia Polyglotta S. C. de Propaganda Fide, Romae, 1903-1906).

Scotus, Ionanni. Opera Omnia. Civitas Vaticana: Typis Polyglottis Vaticanis, 1950-2013). Ordinatio (vol. I-XIV) Lectura (vol. XVI-XXI).

Synge, Edward. A gentleman's religion: in three parts. With an appendix. London: Printed by Richard Sare at Grays-Inn in Holborn, 1697.

Toland, John. Christianity not mysterious, or, A treatise shewing that there is nothing in the Gospel contrary to reason, nor above it and that no Christian doctrine can be properly call sd a mystery. London, 1702. 
Taranto, Pascal. "Berkeley and Browne on Divine Analogy". Presentation at the International Berkeley Society conference "Berkeley In Context" (June 2018).

Van Steenburgh, E. W. "Berkeley Revisited". The Journal of Philosophy 60, no. 4 (February 1963): 85-89.

\section{Summary}

The problem of divine attributes was one of the most intensely debated topics in the 17-18th century Irish philosophy. Simply put, the problem revolves around the ontological question (i) whether human and divine attributes differ in degree or in kind, and the semantical (ii) how we ought to describe these divine attributes by means of our human language. While there was a consensus that analogies play a key role in solving the semantical problem there was a controversy about the kind of speech they allow for. Especially, it was contested if using analogies for divine predication allows for a separate kind of speech, i.e. allows us to speak neither literally nor metaphorically but analogically.

The aim of my paper is to contextualize George Berkeley's position on the problem of divine attributes as developed in $\S 21$ of the IV. Dialogue in Alciphron. More specifically and contrary to what most scholars hold, I argue Berkeley fails to follow Cardinal Cajetan with remarkable closeness. Despite paraphrasing parts of Cajetan's De Nominum Analogia in $\S 21$, the solution Berkeley advances is closer to the position of John Duns Scotus - and hence, ironically, with the position Cajetan aimed to reject.

Keywords: George Berkeley; Cajetan; Aquinas; Scotus; Alciphron: The minute philosopher; divine attributes; divine analogy; Berkeley's notion of analogy

\section{Streszczenie}

\section{A jednak skotysta? George Berkeley, Kajetan i kwestia Bożych atrybutów}

Problem Bożych atrybutów należy do najczęściej dyskutowanych kwestii w filozofii irlandzkiej siedemnastego i osiemnastego stulecia. Krótko mówiąc, dotyczy on zagadnienia (i) ontologicznego: czy atrybuty człowieka i Boga różnią się co do stopnia czy rodzaju, a także (ii) semiotycznego: w jaki sposób, posługując się naszym ludzkim językiem, powinniśmy opisywać owe atrybuty. O ile zgadzano się, że analogie odgrywają kluczową rolę w rozwiązaniu problemu semantycznego, spierano się o to, jaki sposób wyrażania się dopuszczają; chodziło przede wszystkim o to, czy posługiwanie się analogiami podczas orzekania o Bogu stanowi odrębny rodzaj posługiwania się językiem i czy znaczenia przekazywane za pomocą analogii należałoby odróżnić od znaczenia literalnego i metaforycznego. 
Celem mojego artykułu jest kontekstualizacja stanowiska George’a Berkeleya odnośnie do Bożych atrybutów, wyrażonego w 21 paragrafie czwartego dialogu Alkifrona. Dokładniej rzecz ujmując, w przeciwieństwie do tego, co utrzymuje większość badaczy, twierdzę, że Berkeley nie zdołał zbyt dokładnie odtworzyć stanowiska kardynała Kajetana. Chociaż w przytoczonym paragrafie Berkeley parafrazuje jego De Nominum Analogia, zaproponowane przezeń rozstrzygnięcie bliższe jest stanowisku Jana Dunsa Szkota, a więc, o ironio, stanowisku, które Kajetan starał się odrzucić.

Słowa kluczowe: George Berkeley, Kajetan, Tomasz z Akwinu, Duns Szkot, Alkifron, Boże atrybuty, Boża analogia, Berkeleyowskie pojęcie analogii 